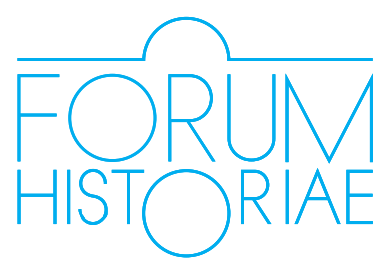

\title{
Vystúpenie z Vel'kej vojny prostredníctvom práva. Československo, jeho menšiny a ich ochrana v Spoločnosti národov*
}

\author{
Bohumila Ferenčuhová
}

\begin{abstract}
:
FERENČUHOVÁ, Bohumila: Exiting the Great War through the Rule of Law. Czechoslovakia, Its Minorities and Their Protection in the League of Nations.

The study applies the French term "sortie de guerre" (exiting the war) to the issues at the end of the Great War in the Habsburg monarchy, Central-Eastern Europe and in Slovakia, which was part of this area. It pays special attention to the issues of the minorities and the search for the possible ways in which they could be protected by international law and the treaties signed after the end of World War I. Exiting the war for Slovaks cannot be considered from a narrow local perspective. It is linked to the decision-making process regarding the exiting the war at the level of the monarch and council of ministers, which is briefly considered in the first section of the study. The second section demonstrates the impact of these decisions on Slovakia. On the basis of the published documents it depicts the situation in the Slovak countryside before the ceasefire was signed on the Italian and Western fronts and the brutalisation of society resulting from the wartime suffering. It points out the danger of its unilateral identification with antisemitism. The issue of the inclusion of Bratislava in the Czechoslovak Republic points to the importance of both social matters as well as military and diplomatic solutions reflected at the local level by the city's inhabitants. The ethnically conciliatory policy of the governor, Samuel Zoch, offered hope for the future. The third section, analyses in detail the reaction of the powers' representatives at the peace conference to the post-war situation in Central-Eastern Europe and the solution of the issue of minorities, on the basis of documents from the Ministry of Foreign Affairs of the French Republic and the League of Nations in Geneva. The conclusion responds to some French studies concerning the "sortie de la Grande Guerre" and their view of the treaties after the Great War. At the same time, it summarises the author's knowledge gained from the work on this study.
\end{abstract}

Keywords: exiting wars, First World War, protection of minorities, League of Nations, Slovakia, Czechoslovakia

$\mathrm{V}$ o svojom príspevku na tému vystúpenie z Vel'kej vojny som sa inšpirovala štúdiou Françoisa Gérého, publikovanou v Revue historique de l'armée už v roku 2006. ${ }^{1}$ Podl'a tohto autora „sortie de guerre“ závisí v prvom rade od pohnútok, ktoré účastníka viedli k vstupu do vojny, a od vojenskej stratégie, ktorou ju viedli. Práve ony určujú vnímanie úlohy vojny v jednotlivých kultúrach, toho, akú úlohu zohrala v jednotlivých spoločnostiach a ako ovplyvnila medziludské vztáhy. Českí a slovenskí vojaci bojovali vo Vel'kej vojne v obidvoch nepriatel'ských táboroch. Ovela viac ich bojovalo na strane ústredných mocností. Zároveň však postupne vznikla z českých a slovenských krajanov, emigrantov a vojenských zajatcov celá armáda, ktorá sa zapojila do bojov proti ústredným mocnostiam

\footnotetext{
* Štúdia vznikla v rámci projektu VEGA 2/0135/15, Vít'azstvo a pád Tretej republiky. Malá dohoda medzi Francúzskom a Talianskom 1914 - 1940. Vedúca projektu B. Ferenčuhová.

1 GÉRÉ, François. La manœuvre de sortie de guerre. In Revue historique des armées, č. 245, 2006, dostupné na internete: http://rha.revues.org/5512 (posledný náhl'ad 6. 5. 2017).
} 
na západnom fronte, talianskom fronte, ruskom fronte a napokon na Sibíri. Mala hodnotu atribútu národnej nezávislosti, ako to zdôraznil v polovici roku 1917 M. R. Štefánik. Vo Francúzsku dekrét o utvorení československej armády 16. decembra 1917 podpísali najvyšší vládni činitelia: prezident Raymond Poincaré, predseda vlády Georges Clemenceau a minister zahraničných vecí Stephen Pichon. Armáda politicky podliehala Československej národnej rade s ústredným sídlom v Paríži a mala bojovat' pod vlastnou zástavou za ciele odboja - čiže zriadenie samostatného československého štátu. V Taliansku vyrokoval M. R. Štefánik zmluvu o zriadení československého vojska v apríli 1918 v mene Československej národnej rady priamo.

Vnútri habsburskej monarchie bola situácia na konci vojny zložitá a nejednoznačná. Strata lojality časti obyvatelov voči monarchii mala celý rad príčin vrátane zlej hospodárskej a sociálnej situácie, nedostatku potravín a hladu. ${ }^{2}$ Napriek tomu sa slovenské vystupovanie z vojny nedá pochopit' len z úzko lokálnej úrovne. Viaže sa na rozhodovanie o vystúpení z vojny na úrovni panovníka a ministerskej rady, ktorého sa stručne dotknem v prvej časti štúdie. V druhej poukážem na dopad týchto rozhodnutí na Slovensko. V tretej časti sa zameriam na reakciu reprezentantov vel'mocí na mierovej konferencii na povojnovú situáciu východno-strednej Európy a na riešenie problematiky menšín.

Ak hovorím o vystúpení z vojny prostredníctvom práva, mám na mysli ten prípad, ked’ vojnovým cielom je „oslobodenie nejakého národa“ a jeho právne ukotvenie. Práve preto považujem za dôležité podčiarknut' znenie nóty, ktorú Wilson adresoval habsburskej monarchii 18. októbra 1918 a to, že martinské Národnie noviny ju zverejnili 22. októbra.

„Präzident pokladá si za povinnost' oznámit' rakúsko-uhorskej vláde, že nemôže sa zapodievat's jej predostretím, lebo od 8. januára isté vel'mi významné udalosti sa stali, ktoré premenili príslušnost' a zodpovednost' severoamerickej vlády. Medzi tými 14. bodmi, ktoré präzident vtedy formuloval, je odsek: „Národom v Uhorsku a Rakúsku, ktorých položenie medzi národmi obránené a zabezpečené chceme vidiet', treba dat' najsvobodnejšiu možnost' autonomného vývinu“. Od tých čias, ako tento bod bol napísaný a na kongrese Spojených štátov vyhlásený, vláda Spojených štátov uznala, že medzi Čecho-Slovákmi a Nemci, ako i medzi uhorskou a rakúskou dŕžavou je vojenský stav a že Česko-slovenská národná rada je skutočnou vojnu vedúcou vládou, ktorá je zaopatrená zodpovedajúcou auktoritou $k$ vedeniu česko-slovenských vojenských a politických vecí. Uznal d'alej i úplnú oprávnenost' ašpirácií Juhoslovanov na národnú svobodu. Präzident preto nie je už v tom stave, že by uznal autonómiu týchto národov, a ko základ pokoja, ale prinútený je držat’sa toho, aby oni sami a nie on súdil nad tým, aká akcia uhorskej a rakúskej vlády uspokojí ašpirácie a poňatia týchto národov o ich právach a určení, prislúchajúcom im ako členom rodiny národov“"3

2 BOISSERIE, Etienne. Tchèques et Slovaques dans l'Autriche-Hongrie en guerre (1914 - 1918) "Nous ne croyons plus aucune promesse ». Manuscrit du dossier d'habilitation à diriger des recherches. (habilitačná práca), Paris : Université Paris 1 Panthéon-Sorbonne, 2015.

3 Slovenský preklad nóty v Národných novinách In Dokumenty slovenskej národnej identity a štátnosti, 1. Bratislava : Národné literárne centrum - Dom slovenskej literatúry, 1998, s. 497, dokument 156. 
Martinskí deklaranti Wilsonovu odpoved’ a terminológiu zohl'adnili 30. októbra 1918.

\section{Výstup z vojny na najvyššej úrovni}

Rozchod Čechov a Slovákov s habsburskou monarchiou a Uhorskom do značnej miery súvisí s vojnovými ciel’mi jej vládcov. Od začiatku vojny až do posledných dní pred jej ukončením k nim patrilo zabránit’ posilneniu Slovanov v ríši a nedopustit’ také štátoprávne usporiadanie, ktoré by im vyhovovalo. Vývoj týchto vojnových ciel'ov podrobne zmapoval Petr Prokš v monografii Vítězové a poražení. Střední Evropa v politických plánech velmocí za Velké války a na mírové konferenci v Paříži 1914 - 1918/1919 - 1920.4 Kritické obdobie pre monarchiu nastalo v septembri 1918, najmä po podpise prímeria Bulharska so Spojencami. Pod vplyvom tejto situácie cisár Karol zvolal 27. septembra 1918 ministerskú radu, na ktorej vyhlásil, že nastal čas rokovat' o vnútornej rekonštrukcii súštátia. Štrnást' mierových podmienok amerického prezidenta Woodrowa Wilsona sa dostalo na program zasadnutia Rady pre spoločné záležitosti Rakúsko-Uhorska 2. októbra. Predseda uhorskej vlády Sándor Wekerle v nich videl vel'ké nebezpečenstvo, zatial' čo sa predseda rakúskej Hussarek domnieval, že „Wilsonove požiadavky [síce] vychádzajú v ústrety autonómnym snahám jednotlivých národov, ale môžu poslúžit' aj na rekonštrukciu a regeneráciu Rakúska“. ${ }^{5}$ Vzhl'adom na vnútorné nepokoje a situáciu na frontoch, od ktorej sa nedalo očakávat' nič dobré, Rakúsko-Uhorsko požiadalo 5. októbra prostredníctvom neutrálneho Švédska Woodrowa Wilsona o okamžité začatie vyjednávania o mieri. 0 štátoprávnu reformu sa panovník pokúsil vydaním manifestu zo 16. októbra o ústavnej premene dvojmonarchie na spolkový štát zložený z českého, nemecko-rakúskeho, juhoslovanského a ukrajinského štátu. Táto premena sa mala týkat' pôvodne celej monarchie, ale panovník cúvol pred neústupnostou uhorského predsedu vlády. Manifest zverejnený o deň neskôr vyhlásil premenu Rakúska na spolkový štát; každý národ si podla neho mohol zriadit’ štát na vlastnom území. Spojenie pol'ských území Rakúska s pol’ským nezávislým štátom sa nevylučovalo. Terst mal získat’ zvláštny štatút. Plánovaná úprava sa nijako nemala dotknút' územnej celistvosti Uhorska, platila len pre Predlitavsko. Napriek tomu uhorský parlament reagoval na cisársky manifest zo 16. októbra uvol'nením zväzku s Rakúskom, s ktorým mala Uhorsko nad’alej spájat' len personálna únia. Požiadavky opozície boli ešte d’alekosiahlejšie. Dňa 17. októbra 1918 parlament odhlasoval, aby sa mad’arské pluky okamžite vrátili domov na obranu ohrozeného Uhorska. Tým sa urýchlil rozklad armády, pretože z frontu aj posádok začali utekat' po mad’arských vojakoch aj vojaci ostatných národností. Dňa 18. októbra prišla Wilsonova odpoved' na žiadost' habsburskej monarchie začat' mierové rokovania na základe jeho štrnástich bodov. Skoro všetky periodiká v monarchii zverejnili konštatovanie amerického prezidenta, že Dohoda uznala Čecho-Slovákov a Juhoslovanov ako spojencov vo vojne a uznala aj ich nároky na oslobodenie.

4 PROKŠ, Petr. Vítězové a poražení. Střední Evropa v politických plánech velmocí za Velké války a na mírové konferenci v Pařízi (1914 - 1918/1919 - 1920). Praha : Naše vojsko, 2016.

5 Tamže, s. 54. 
Preto je teraz na nich, aby rozhodli, čo ich požiadavky uspokojí. Posledná ministerská rada Rakúsko-Uhorska vo Viedni za prítomnosti panovníka rozhodla, že je nevyhnutné v mierovej akcii pokračovat', neurobit' nič také, čo by ohrozilo obrannú silu armády a zastavit' odstredivé tendencie. To však už nebolo možné. Po cisárskom manifeste zo 16. októbra a zverejnení Wilsonovej nóty najrýchlejšie zareagovali nemeckí poslanci ríšskej rady z celého Predlitavska. Dňa 21. októbra založili dočasné národné zhromaždenie, ktoré vyhlásilo nový štát - Deutsch-Österreich, kam mali patrit' aj územia obývané etnickými Nemcami z Čiech, Moravy a Sliezska; 27. októbra minister zahraničných vecí Gyula Andrássy odpovedal Wilsonovi, že monarchia súhlasí s jeho názorom o „právach národov rakúsko-uhorských, najmä o právach Čechov, Slovákov a Juhoslovanov",6 prijíma všetky jeho podmienky a žiada o okamžité prímerie na všetkých frontoch a zahájenie mierových rokovaní. Nóta bola zverejnená 28. októbra $1918 .{ }^{7}$ Kým štátna rada ju považovala za cestu k záchrane monarchie, obyvatel'stvo Prahy si ju vysvetlilo ako bezpodmienečnú kapituláciu a vlastné vít’azstvo.

Petr Prokš výstižne rezumuje túto kapitolu vystúpenia Rakúsko-Uhorska z vojny. Citujem v slovenskom preklade: „Predáci predlitavských Nemcov svojím predošlým nacionalizmom a vyhlásením Nemeckého Rakúska a predstavitelia Uhorska svojou neústupnostou v záležitosti vnútorných reforiem, úpornou snahou o čo najväčšie rozšírenie uhorskej samostatnosti v rámci podunajského súštátia aj odvolaním mad'arských plukov domov v skutočnosti sami v podmienkach vyhrotených sociálnych a národnostných rozporov odštartovali živelný politický a územný rozpad habsburskej ríše, čo rázne využili predstavitelia slovanských národov na naplnenie svojich štátoprávnych požiadaviek. Na prelome októbra a novembra 1918 sa preto Rakúsko-Uhorsko rozpadlo na jednotlivé „nástupnícke“ štáty. Československo 28. a 30. októbra 1918, Juhoslávia 29. októbra 1918, Pol'sko 29. októbra 1918, Rakúsko 12. novembra 1918 a Mad’arsko 16. novembra 1918. Okrem toho z územia bývalej habsburskej monarchie Taliansko získalo územie Terstu a Tridentu a Rumunsko zase Bukovinu a Sedmohradsko."

\section{Slovenský výstup z vojny}

\section{Vidiek}

V druhej polovici októbra a začiatkom novembra 1918 monarchiu zachvátila revolúcia a ocitla sa na pokraji občianskej vojny. To platí pre Viedeň, Budapešt', České krajiny, Halič aj pre Slovensko. Na území obývanom Slovákmi vypukli nepokoje v súvislosti s návratom vojakov $\mathrm{z}$ frontu a ich útekmi od posádok vo vnútrozemí. Vojaci boli unavení, špinaví a najmä hladní. Pri návrate domov nenašli v komorách nič. Vojaci sa dožadovali slúbených demobilizačných po-

6 Kapitulácia Rakúsko-Uhorska a uznanie práv Čechoslovákov v odpovedi gr. Andrássyho prezidentovi Wilsonovi 27. okt. 1918. In MEDVECKÝ, Karol A. Slovenský prevrat, 3. Bratislava : Komenský, Vydavatel'ská a literárna spol. s r. o., 1930, s. 363.

7 PROKŠ, Peter. Poslední pokusy o záchranu a přestavbu Rakousko-Uherska (květen-listopad 1918). In Slovanský přehled, Review for Central, Eastern and Southeastern European History, 1/2008, s. 1-13.

8 Tamže, s. 12-13. 
platkov a útočili kvôli nim na notárov. Dediny najmä na severozápadnom a severnom Slovensku boli vyhladované a židovské obchody a krčmy vyplienené, často s mimoriadnou brutalitou. Násilníci sa opili, majitel'ov zbili, neraz až na smrt'. S odvetou neváhali ani mad’arskí žandári či občasné oddiely pravidelného vojska. Násilnosti vrcholili 2. - 4. novembra 1918. Nesúviseli s 28. októbrom v Prahe ani s Martinskou deklaráciou, skôr boli súčastou celouhorskej revolúcie. $^{9}$ O vzniku Československej republiky sa obyvatelia zväčša ešte nedopočuli. Heslom bola sloboda a rovnost'. Vojaci obyvatel'om hovorili, že nastala sloboda. Boli slobodní, lebo nemuseli poslúchat' svojich velitelov, a boli slobodní, lebo sa mohli pomstit' pánom. Slobodu si predstavovali ako totálnu anarchiu. ${ }^{10} \mathrm{~V}$ Topol'čanoch na stanici sa síce pokúsili vojakom odobrat' náboje, pušky, revolvery, ale nie celkom úspešne. Takže potom demobilizovaní vojaci spoločne s obyvatel'mi okolitých dedín nelútostne drancovali obchody. „Bola sloboda, mohol teda každý robit', čo chcel. Raboval, ničil, pálil, majetok svojich pánov, nevediac, že i sám si škodí." [...] „V meste nebolo nijakej bezpečnosti. Nikto nevedel, kto vládne, či prídu Česi a či ostane bývalá vláda rakúsko-uhorská". Ale boli i takí, čo si chceli vládnut' sami. Jeden robotník, ktorý bol vodcom výtržníkov, šiel v ukradnutom fraku s cylindrom na hlave po hlavnej ulici v Topolčanoch a furiantsky vyhlasoval: „Som ministrom, mne nikto nerozkazuje, lebo ja sa nikoho nebojím." ${ }^{11}$

Na otázku slovenského farára, učitela a bankového úradníka „Čo nového vo svete? Odpovedali vracajúci sa vojaci: Všeličo, prosím. Vojnu sme št'astne prehrali. Tol'ko trpiet' a hladovat' a dat'sa zabíjat' pre nič za nič, len preto, že to tak páni chceli mat'.12 $^{\prime \prime}$

Farári konštatovali stratu náboženských a mravných hodnôt. Prevrat podla nich celkom zmenil zmýšlanie l'udu. Asi dva týždne kostol bol prázdny a deti do školy nechodili. Situácia sa upokojila až v decembri. Chudoba nemala zárobku, a tak nemala čo jest'. Asi cez dva mesiace občiansku bezpečnost' chránila národná stráž zložená z mad’arských i slovenských obyvatelov stredných vrstiev. Do Veselého nad Váhom na obranu vel'kostatkárov poslali platených mad’arských vojakov z Budapešti. ${ }^{13}$

Opisy týchto „rabovačiek“ v mnohých obciach a mestečkách zozbieral a uverejnil člen SNR a potom povereník Šrobárovho ministerstva s plnou mocou pre správu Slovenska Karol Anton Medvecký. Dnes ich niektorí bádatelia skúmajú podrobnejšie na základe archívnych dokumentov, pričom ich interpretáciu neraz posúvajú do roviny slovenského a českého antisemitizmu, a tiež zakrývania

9 Pozri FERENČUHOVÁ, Bohumila - KRAJČOVIČOVÁ, Natália. Vznik Československa a začlenenie Slovenska do nového štátu. In FERENČUHOVÁ, Bohumila - ZEMKO, Milan a kol. Slovensko v 20. storočí. Tretí zväzok. V medzivojnovom Československu 1918 - 1939. Bratislava : Veda, Historický ústav SAV, 2012, s. 17-58.

10 MEDVECKÝ 1930, s. 156.

11 Tamže, s. 155.

12 Tamže, s. 36.

13 Tamže, s. 59-60. 
odvetných opatrení zo strany obrancov obetí týchto excesov. ${ }^{14}$ Ďalší bádatelia, napríklad Marián Hronský ${ }^{15}$ a Ismo Nurmi, ${ }^{16}$ podčiarkli, že obdobie vzbúr trvalo krátko a aktivity Slovenskej národnej rady ustanovenej 30. októbra boli úspešné. Jej členovia chodili po Slovensku a propagovali vznik Česko-slovenskej republiky. Po Martinskej deklarácii vznikali na Slovensku okrem ústrednej aj miestne národné rady a gardy, inde sa nazývali národné výbory a národné stráže. Na mnohých miestach preberali moc a pôsobili na obyvatel'stvo upokojujúco. Hlásili sa k Martinskej deklarácii, ústrednej martinskej SNR a k samostatnej Česko-slovenskej republike. SNR zaregistrovala po 8. novembri asi tristo miestnych slovenských rád. ${ }^{17}$ Príchod prvých vojenských jednotiek z Čiech tiež na viacerých miestach zasiahol represívne proti nepokojom a lúpežiam, ktorých sa na západnom Slovensku dopúštali aj utečenci zo zajateckých táborov a zbehlí vojaci, skrývajúci sa už niekol'ko mesiacov v západných Karpatoch.

\section{Medzinárodné súvislosti slovenského výstupu z vojny}

Na rokovaniach o posledných vojnových operáciách a podmienkach prímeria v Paríži 4. novembra 1918 Edvard Beneš ako predstavitel' spojeneckého a vojnu vedúceho národa uznaného postupne Francúzskom, Anglickom, Talianskom, USA a Japonskom informoval, že Národný výbor prevzal 28. októbra moc v Prahe, a tiež, že väčšina slovenského územia je už pevne v československých rukách. Podkladom posledného tvrdenia bola asi informácia, že Národný výbor vyslal na Slovensko Vavra Šrobára, Ivana Dérera, Antona Štefánka a Pavla Blahu, ktorí utvorili slovenskú vládu v Skalici. Mohli sa pri tom opriet’ o nepatrnú vojenskú silu - stovku četníkov a o slovenskú légiu - pôvodne 25. peší pluk z Lučenca vracajúci sa z talianskeho frontu. ${ }^{18}$ Táto situácia však nemala dlhé trvanie. Vláda Mad’arskej republiky na čele s M. Károlyim sa pokúsila zvládnut' situáciu diplomaticky aj vojenskou cestou. Kým bývalý umiernený mad’arský minister obrany Béla Linder podpisoval v Belehrade dohodu o prímerí na fronte s vojenským velitel'om spojeneckých vojsk, jeho nástupca Béla Bártha sa odhodlal rozhodne zakročit' a vyslal v polovici novembra 1918 na obranu uhorských hraníc vojsko. Mohol sa opriet’ o vojenské posádky v Košiciach, Lučenci, Nových Zámkoch a Prešporku i o dobrovol'nícke mad’arské gardy na Slovensku. Nariadil mobilizáciu ročníkov 1896 - 1900. Vojenská jednotka v sile jedného práporu postúpila zo Zvolena cez Kremnicu do Turca a zmocnila sa Turčianskeho Sv. Martina, sídla SNR, a zatkla jej predsedu M. Dulu a evanjelického farára O. Škrovinu. Zabezpečila pre mad’arskú vládu strategicky dôležité dopravné uzly Vrútky a Žilinu.

14 SZABÓ, Miloslav. „Rabovačky“ v závere prvej svetovej vojny a ich ohlas na medzivojnovom Slovensku. In Forum Historiae, 2015, roč. 9, č. 2, s. 35-55; SZABÓ, Miloslav. „Židovská hrôzovláda“ v dobe prevratu? Kampane proti židovským dôstojníkom a antisemitizmus na medzivojnovom Slovensku. In MANNOVÁ, Elena - DUDEKOVÁ, Gabriela a kol. Vojak medzi civilmi. Civil medzi vojakmi. Vzt'ah armády a spoločnosti v období modernizácie. Bratislava : Spoločnost' Pro historia, 2017, s. 239-259.

15 HRONSKÝ, Marián. Slovensko pri zrode Československa. Bratislava : Pravda, 1987.

16 NURMI, Ismo. Slovakia a Playground for Nationalism and National Identity, 1918 - 1920. Manifestations of the National Identity of Slovaks. Helsinki : Suomen Historiallinen Seura, 1999.

17 HRONSKÝ, Marián. Vznik a činnost’ druhej slovenskej národnej rady (1918 - 1919). In PEKNÍK, Miroslav (ed.) Slovenské národné rady. Bratislava : Národné literárne centrum - Dom slovenskej literatúry, 1998, s. 64. 18 FERENČUHOVÁ - ZEMKO 2012, s. 29. 
Koncom novembra pod československou kontrolou ostal len úzky pás Považia od Vel'kej Bytče po Nové Mesto nad Váhom a juhozápadný výbežok Slovenska, ale bez Trnavy a Bratislavy. Na okupovaných územiach bolo obyvatel'stvo prenasledované zo strany mad’arských ozbrojených síl.

Proti vojenským zásahom na Slovensku a proti Dulovmu zatknutiu protestoval u Károlyiho prvý československý zástupca v Budapešti Emil Stodola. Károlyi mu vyšiel v ústrety najmä ako zástupcovi Slovenskej národnej rady, ktorej navrhoval kooperáciu pri udržiavaní poriadku a pokoja, posty županov na Slovensku a spoluprácu vo vol'bách do uhorského parlamentu. Stodola ponuky odmietol a informoval o nich Prahu. V zložitej situácii ministerský predseda Karel Kramář poveril zastupovaním československých záujmov v Budapešti Milana Hodžu, na ktorého sa národnostne zmierlivý člen Károlyiho vlády Oszkár Jászi obrátil s ponukou rokovat' o „slovenskom impériu“ v rámci Uhorska, pričom termín označoval určitú obmedzenú formu autonómie. Do hry vstúpilo Benešovo úsilie v Paríži o súhlas s presunom čs. zahraničného vojska na požadované československé územie, o stanovenie demarkačnej čiary medzi Československom a Mad’arskom na pomoc pri konsolidovaní nového štátu, diplomatická pomoc Francúzska a vyslanie talianskej a francúzskej vojenskej misie do Československa. Vel'ký význam malo potvrdenie Československa ako spojenca z 1. decembra 1918. „Spojenci uznali Československý štát, jeho armádu uznali ako spojeneckú armádu, prijali jeho zástupcu na konferenciách vo Versailles, ktoré stanovili podmienky rakúsko-uhorského prímeria. Československý štát má teda právo okupovat'slovenské územia, hoci ich hranice treba ešte delimitovat' už aj z toho titulu, že sa ako bojujúci spojenci podiel'ajú na exekúcii prímeria, ktoré naplánovalo okupáciu území bývalej rakúsko-uhorskej monarchie." ${ }^{\text {"19 }}$

Zároveň bola pražskej vláde adresovaná výčitka, že s krajinami ako Rakúsko, Nemecko a Mad'arsko, ktoré vo vojne utrpeli porážku, rokovala a nadväzovala styky, hoci vít'azné mocnosti ich vlády zatial' neuznali ani priamo s nimi nerokovali. Ak sa stredná Európa chcela vyhnút' revolučným výbuchom a väčším krvavým zrážkam, iného východiska ako rokovanie však nebolo.

\section{Výstup z vojny v Bratislave}

Na tomto mieste sa nebudem zaoberat' problematikou stanovenia československo-mad’arskej štátnej hranice, nebudem venovat' pozornost' konfliktu o ňu s Mad'arskou republikou rád, ani peripetiám okolo Trianonskej zmluvy až do jej ratifikácie a vstupu do platnosti z medzinárodnopolitického hladiska, čo sa stalo až 26. júla $1921^{20}$. Budú ma zaujímat’ skôr pokusy o zmierlivé riešenie národnostných a sociálnych konfliktov. Z tohto hladiska je príznačný príklad

19 Tamže, s. 33.

20 Pozri Tamže, s. 17-92; HRONSKÝ, Marián. Trianon. Vznik hraníc Slovenska a problémy jeho bezpečnosti (1918 - 1920). Bratislava : Veda, 2011; FERENČUHOVÁ, Bohumila. Na ceste k Trianonu - československomad'arsko-rumunské konfrontácie na jar 1919. In PETRUF, Pavol (ed.) Slovensko a Československo v XX. storočí, vybrané kapitoly z dejín vnútornej i zahraničnej politiky. K 70. narodeninám PhDr. Dagmar ČiernejLamtayovej, DrSc. Bratislava : Veda, 2010, s. 23-35; v týchto publikáciách sú odkazy na d’alšiu početnú historickú literatúru. 
Prešporka - Wilsonovho mesta - Bratislavy. Na žiadost’ Vavra Šrobára v Ministerskej rade v Prahe sa od 13. marca 1919 názov mesta oficiálne ustálil ako Bratislava. ${ }^{21}$ Kvôli polohe na Dunaji a významu z hladiska slovenských kultúrnych dejín sa s jej pričlenením k ČSR rátalo už v prvých náčrtoch podoby požadovaného štátu, čo neplatilo napríklad pre Žitný ostrov, s pričlenením ktorého si napríklad T. G. Masaryk nebol vždy celkom istý. Podla uhorského sčítania l'udu z roku 1910 žilo v Prešporku 78223 obyvatelov. Tesnú relatívnu väčšinu 41,9 \% (32 790 osôb) z nich malo nemecké obyvatel'stvo, podiel mad'arského obyvatel'stva, ktoré počtom v posledných rokoch vel'mi narastalo, bol 40,5 \% (31 705 osôb), slovenského 14,9 \% (11 673 osôb) a inojazyčného 2,6 \% (2 055 osôb). ${ }^{22}$ Definitívne začlenenie Bratislavy do ČSR prinieslo aj zmeny v počte a národnostnom zložení obyvatel'stva. Podl'a sčítania l'udu z roku 1930 mala Bratislava 123844 obyvatelov, teda o 45621 viac ako v roku 1910. Česi a Slováci spolu predstavovali 51,34 \%. V absolútnych číslach bolo najviac Slovákov - 34836 občanov (29,80 \%), Nemcov 32801 (28,06 \%), Čechov 25177 (21,54 \%), Mad'arov 18890 (16,61 \%), Židov 4747 (4,06 \%), ale obyvatelov izraelitského vierovyznania bolo trojnásobne viac (14 822) a inej národnosti $446(0,38$ \%). Milan Zemko, ktorý tieto počty vyčíslil na základe štatistík, hovorí o posilnení multietnicity mesta bez výraznejšej prevahy jednej jazykovej skupiny, a tiež o pretrvávajúcej kultúrnej a politickej bipolarite medzi pôvodnými Prešporákmi a prist’ahovanými Bratislavčanmi. ${ }^{23}$

V jeseni 1918 bolo v Prešporku posádkové velitel'stvo, takže sa vyhlo drancovaniu podobne ako iné mestá s pravidelnou posádkou. Milan Hodža ho tak ako Košice ponechal za dočasnou demarkačnou čiarou dohodnutou v Budapešti 6. decembra 1918, za ktorú sa mali stiahnut’ vojská Mad’arskej republiky. Situácia sa zmenila po oznámení demarkačnej čiary z Paríža tesne pred Vianocami a po príchode československých legionárov z Talianska pod velením generála Luigiho Piccioneho. Až do schválenia mierovou konferenciou mala platit’ ako dočasná hranica. Rozsiahla publikácia dokumentov Pripojenie Bratislavy $k$ Československej republike roku 1918 - $1919^{24}$ prezrádza vel’a o postoji obyvatel’ov Prešporka k novej príslušnosti mesta. S príslušnostou k Československu sa nechceli zmierit', nechceli sa stat’ menšinou. Nelákali ich predstavy Čechov o zvýšení významu mesta a jeho hospodárskom raste $\mathrm{v}$ budúcnosti. Po skúsenostiach z rokovaní s československým zástupcom Vlastimilom Tusarom vo Viedni popredný činitel' nemecko-mad’arskej radikálno-demokratickej meštianskej strany v Prešporku Max Fejér konštatoval, že Česi k záležitosti pristupujú ako vít’azi a dohoda im sl'úbila Prešporok. Jeho obyvatelia sa teda nemôžu spol'ahnút’ na Wilsonov princíp sebaurčenia. ${ }^{25}$ Navrhol preto, aby sa po vyčerpaní možnosti bud' ostat' v Uhorsku,

21 HORVÁTH, Vladimír - RÁKOŠ, Elemér - WATZKA, Jozef. Pripojenie Bratislavy $k$ Československej republike roku 1918 - 1919. Dokumenty. Bratislava : Obzor, 1977, s. 317, dokument 165.

22 ZEMKO, Milan. Slovakizácia Bratislavy v 20. storočí podla štatistík. In FERENČUHOVÁ, Bohumila (ed.) Slovensko a svet v 20. storočí. Kapitoly $k$ 70. narodeninám Valeriána Bystrického. Bratislava : Historický ústav Slovenskej Akadémie vied, 2006, s. 27.

23 ZEMKO 2006, s. 31.

24 HORVÁTH - RÁKOŠ - WATZKA 1977.

25 Tamže, s. 121-122, dokument 16. 
alebo sa pripojit' k Rakúsku, z mesta vytvorila samosprávna nezávislá republika na spôsob nemeckých hanzovných miest. ${ }^{26}$ Počut' však aj racionálnejšie hlasy. Hovoria o hospodárskom a strategickom význame Prešporka, čoho si bol vedomý už Napoleon. 0 dôležitosti Devína a sútoku Moravy s Dunajom, a tiež o prepojení s cestou do Trnavy, ako aj toho, že mesto nemôže prosperovat' bez svojho zázemia, ktoré je primalé na nejaký kantón či už v rámci česko-slovenského štátu, alebo „slovenského impéria“ v rámci Mad’arska. 0 príslušnosti mesta rozhodne mierová konferencia. Alebo ho ponechá v Mad’arsku, alebo mu nadiktuje inú štátnu príslušnost'. Preto Nemecká rada v Prešporku prijala uznesenie, že postavit' sa na odpor pravidelným českým vojenským silám by ohrozovalo život a majetok obyvatel'stva. Prečo by mali nechat' ničit' svoje polia a vinice, nechat' si zbúrat' domy a platit' vysoké vojenské kontribúcie? To by nebolo ani humánne, ani vlastenecké, ani nevyhnutné. ${ }^{27}$ Vojenská rada sa rozhodla bránit' mesto pred nepravidelnými a lúpežnými bandami, ale mesto ako celok bolo ochotné sklonit' sa pred pravidelnou spojeneckou armádou zloženou z piatich až šiestich tisícok mužov. Odovzdanie mesta v hlavných rysoch dohodol 23. decembra 1918 vrchný župan Prešporka Zoltán Jankó s novovymenovaným československým županom - modranským farárom a autorom textu Martinskej deklarácie Samuelom Zochom. Dospeli k dohode, že vojská vstúpia do mesta až po sviatkoch v prvých januárových dňoch a operácia bude mat' politický, nie vojensko-okupačný charakter. K menším bojom došlo najmä v okolí továrne na dynamit. Od 4. januára však generál Luigi Piccione dal generálovi Giuseppe Borianimu rozkaz zaviest' vojenské opatrenia vyplývajúce $\mathrm{z}$ obsadenia Bratislavy. Týkali sa vyčistenia mesta od mad’arských vojakov, ktorí v ňom ostali, zablokovania mosta cez Dunaj a odrezania obyvatel'stva od Petržalky a d'alších nepríjemných opatrení. Rozpustenie uhorských župných orgánov a zavedenie novej československej štátnej správy bolo úlohou Samuela Zocha. Z Bratislavy chcel urobit' hlavné mesto slovenskej časti československého štátu. Tak to uviedol vo svojej prvej vyhláške zo 4. januára $1919 .{ }^{28}$ Bol plný dobrej vôle aj voči mad’arským a nemeckým obyvatel'om Prešporka. Hoci podla Zákona o mimoriadnych prechodných opatreniach na Slovensku (č. 64, ZZ ČSR, zo dňa 10. decembra 1918) bola „úradnou rečou na celom území Slovenska reč slovenská a úrady sú povinné výlučne len slovenskú reč užívat" ${ }^{\prime 29}$, Zoch nariadil, že "na tom území stolice, kde bývajú neslováci, sa môže úradovat' aj v mad'arskej a nemeckej reči' ${ }^{\prime 30}$ Mestá a obce, ktorých sa to týkalo, mienil vymenovat' v zvláštnom nariadení. Ubezpečil nemecky a mad’arsky hovoriace obyvatel'stvo, že Slováci sa budú správat' voči nim podla zásady Jána Kollára „Sám svobody kdo hoden, svobodu zná vážiti každou“, že československá vláda bude rešpektovat' ich občianske práva vrátane možnosti rozvíjat' vlastnú kultúru a jazyk. Ubezpečil ich, že v meste bude nad’alej nemecké divadlo a bude domovom nemeckej kultúry. Úrad župana bratislavskej stolice prevzal 7. januára

26 Tamže, s. 122, dokument 16.

27 Tamže, s. 149-151, dokument 36.

28 Tamže, s. 168, dokument 55 .

29 Tamže, s. 167, dokument 54.

30 Tamže, s. 167, dokument 54. 
a po proteste Zoltána Janka dal do mad’arsky písanej tlače vyjadrenie, že chápe bolest', ktorú pocit'ujú, ale bude sa usilovat' robit' opatrenia prospešné pre priatel'ské spolužitie, a tiež garantovat' bezpečnost' mesta. Chcel z neho spravit' dôležité hospodárske a kultúrne centrum (slovenskej) krajiny a počítal pritom s pomocou a spoluprácou všetkých jeho obyvatelov. Nevyžadoval prísahu Československej republike, ale privítal a prijal slávnostný prejav lojality, ktorý po starosvetsky urobil uhorský minister vo výslužbe a bývalý župan gróf Jozef Zichy: „Podla mojej viery a môjho presvedčenia každá moc pochádza od Boha. Teraz, ked' táto moc prostredníctvom božskej Prozretel'nosti v tejto časti Uhorska bola prenesená na československú vládu, dávam toto slávnostné vyhlásenie: vám a vašej vláde telom i dušou verne slúžit". 31

Opozícia robotníctva a chudobných vrstiev, odrezaných navyše od zdrojov potravy, najmä mlieka z Petržalky, však neutíchala. Zoch sa st'ažoval na existenciu robotníckych a červených gárd schopných rabovania. Bol nútený zakázat' kolportáž mad’arskej tlače a požadoval od vojenského velenia aj zákaz schôdzí. Napriek tomu od prevzatia úradu v januári pripravoval slávnostné presídlenie Šrobárovho ministerstva s plnou mocou zo Žiliny do Bratislavy. Táto správa sa stretla s nesúhlasom najmä nemeckých a mad’arských sociálnych demokratov, ktorí zorganizovali štrajk železníc, čo viedlo k ich prepúštaniu a náboru českých železničiarov na ich miesta. Odmietnutie akademického senátu Alžbetínskej univerzity zúčastnit' sa na privítaní Šrobárovej vlády pre ňu znamenalo koniec existencie. Program na túto slávnostnú udalost’ bol pripravený starostlivo: výzdoba so slávobránami, promenádne koncerty, recepcie v sálach Reduty aj župného domu, predstavenie opery Predaná nevesta v Mestskom divadle, krojované skupiny. Situácia sa však skomplikovala. Čast' vojska bola z Bratislavy odvelená na Tešínsko, kde vypukol územný konflikt s Poliakmi. Zoch riešil poriadkovú službu pozvaním Sokolov z Břeclavi, Uherského Hradišt’a, Hodonína aj z Prahy. S poslednými pricestoval aj minister národnej obrany Václav Klofáč. Práve on dal rozhodný pokyn na skončenie umiernenej politiky voči bývalým úradníkom mad’arskej a nemeckej národnosti. „Neblahé zkušenosti posledních dnů na Slovensku a zvláště př́pad prešpurský (slavnostní vjezd zemské vlády na Slovensku dra Šrobára do Prešpurku byl zmařen passivní resistencí a stávkou mad'arských úředníků a zř́zenců ponechaných prozatím ve službě Československé republiky) vyžadují bezodkladné vyměnění veškerých mad'arských důstojníků, úředníků a vojínů dosud v našich službách ponechaných. [...] S ohledu na důležitost této nutnosti nesmí se poukazovati jako dosud na to, že personálu československého pro výměnu Mad'arů není. [...] Případy, že z rozkazu ministerstva národní obrany na Slovensko vyslaný materiál s odchodem otálí, a proti odchodu činěny byly z mnohých stran námitky, nesmí býti trpěny“.32 Tento rozkaz sa vykonával prostredníctvom vrchného velitel’stva východnej skupiny československých vojsk so sídlom v Kroměříži. Šrobár po presídlení svojho ministerstva do Bratislavy prevzal od velitela vojska v meste plukovníka Riccarda Barrecu správu verejných

31 Tamže, s. 173, dokument 58.

32 Tamže, s. 254, dokument 123. 
záležitostí. Ten sa síce zaviazal, že bude nad’alej dohliadat' na bezpečnost' plynárne, vodovodu a dynamitky, ale odmietol vydat' zákaz verejných zhromaždení robotníkov, lebo to už vraj nebolo v jeho kompetencii. ${ }^{33}$ Závažné bolo, že sa prejavili rozpory aj v československom vojsku, a to medzi legionármi a velitelom Barrecom. ${ }^{34}$ Obyvatel'stvo sympatizujúce s politickou l'avicou vycítilo absenciu vojenskej autority a súladu medzi vojenskou a civilnou mocou. Štrajkujúci železničiari a spojári spolitizovali mzdové požiadavky, žiadali ponechat’ nemecký a mad'arský jazyk v školách, úradoch i zamestnaní, mad’arské nápisy a názvy, a tiež vol'ný predaj mad'arskej a nemeckej necenzurovanej tlače. Na podporu týchto požiadaviek Robotnícka rada zvolala na 12. februára 1919 verejné zhromaždenie. Dav počas neho búrlivo pozdravoval velitela Barrecu, ktorého na oplátku ktorýsi legionár udrel pažbou pušky po hlave. Vojenská hliadka zhromaždenie rozohnala strel'bou. Pri tomto zbytočnom krvavom incidente prišlo o život osem obyvatel'ov mesta a viac ako tri desiatky bolo zranených. ${ }^{35}$ Šrobár v ten istý deň vyhlásil v Bratislave stanné právo. ${ }^{36}$ Situáciu mu pomohla upokojit’ nóta z Paríža adresovaná 18. januára vláde v Budapešti: „Prímerie, ktoré sme podpísali, týkalo sa výlučne len fronty východnej armády a nemá vôbec žiadneho vplyvu na pozdejšie rozhodnutie spojencov na frontách iných. Preto štát československý, spojencami uznaný, má právo absolútnej suverenity na teritóriá, ktoré okupoval už v rozmeroch dočasných hraníc, ktoré sú určené. ${ }^{37}$ Dňa 19. februára 1919 sa štrajk v Bratislave skončil.

Nepokoje v Bratislave mali aj medzinárodný rozmer. Splnomocnenec Československej republiky v Budapešti Ivan Krno hlásil, že výstraha mierovej konferencie ohl'adom politiky faits accomplis ... „dodala mad'arským nádejám nového života; mad'arská žurnalistika komentuje túto rezolúciu v tom zmysle, že je namierená v prvom rade proti okupácii Uhorska československým, rumunským a srbským vojskom. Ďalej posmel'uje Mad'arov tá okolnost', že mierová konferencia dosial' neurčila hranice našeho štátu. Mad'ari kladú svoje nádeje najmä na Wilsona v Anglii [sic!]. Hlásajú, že oni chcú len uskutočnenie 14 bodov amerického presidenta, dla ktorých vôl'a l'udu (tedy plebiscit) má byt’smerodajná pri riešení každej teritoriálnej otázky. Dúfajú, že pri plebiscite obyvatel'stvo Slovenska čiastočne z nevedomosti a politickej nevyspelosti, čiastočne pod tlakom mad’arsko-židovskej agitácie, podporovanej vyživovacími nesnádzami, vyslovilo by sa proti pripojeniu k Česko-slovenskej republike“.38

Podl’a Krnu februárový štrajk v Bratislave bol čiastočne zinscenovaný agitátormi z Budapešti. Jeho príprav sa osobne zúčastnil podla vlastného priznania socialista a člen Hornouhorskej ligy Pavol Dénes.

Na rokovaniach medzi Šrobárom a generálom Piccionem 13. februára v Bratislave dominovala snaha urovnat' vzájomné vztahy medzi talianskymi velitel'mi,

33 Tamže, s. 205, dokument 126.

34 Slovenský národný archív (SNA), Bratislava, OF Vavro Šrobár, šk. 4, i. č. 20, 1. 98.

35 Slovenská národná knižnica, Literárny archív, (SNK LA), OF Vavro Šrobár, 173 M 2; KRAJČOVIČOVÁ, Natália. Vnútropolitický vývoj na Slovensku 1918 - 1920. In FERENČUHOVÁ - ZEMKO 2012, s. 41.

36 HORVÁTH - RÁKOŠ - WATZKA 1977, s. 274-275, dokument 134.

37 Tamže, s. 275-276, dokument 135.

38 Tamže, s. 283, dokument 139. 
československými velitel'mi a slovenskou výkonnou mocou. Generál Piccione v záujme zlepšenia vztahov vo vojsku navrhol, že vrchné velitel'stvo sa presídli z Kroměříža do Bratislavy, čo Šrobár uvítal. Zo svojej strany žiadal, aby talianski dôstojníci zjavne nenadŕžali mad’arskému obyvatel’stvu, nezasahovali do výkonu administrácie a súdnictva, hl'adali družné styky s legionárskymi dôstojníkmi a vojskom a napokon žiadal aj odvolanie plukovníka Barrecu. Piccione mu vo všetkom vyšiel v ústrety, do Bratislavy sa presídlil 7. marca 1919 a za nového posádkového velitel’a bol vymenovaný podplukovník Giuseppe Cajo. ${ }^{39}$

Šrobár opätovne vyhlásil stanné právo v Bratislave v súvislosti s nastolením Mad’arskej republiky rád 25. marca. Zanedlho konflikt získal medzinárodný charakter. Za čiastočne ukončený ho možno považovat' prijatím rozhodnutia o československo-mad’arskej hranici z 19. júna 1919 a pričlenením Petržalky k Bratislave 14. augusta 1919.

\section{Riešenie problematiky menšín v stredno-východnej Európe na základe medzinárodného práva}

V tretej časti sa presunieme na mierovú konferenciu do Paríža. Už v rámci rokovaní o založení Spoločnosti národov Woodrow Wilson navrhoval, aby Pakt Spoločnosti národov podmienil uznanie nových nezávislých štátov vítaznými vel'mocami záväzkom poskytnút' všetkým etnickým a náboženským menšinám rovnaké faktické a právne zabezpečenie ako vlastnému väčšinovému obyvatel'stvu. Neskôr návrh doplnil o článok nasledujúceho znenia: „Uznávajúc, že náboženské perzekúcie a intolerancia vedú k vojnám [...] Spoločnost' národov bude žiadat', aby sa všetky nové a novoprijímané štáty zaviazali, že neprijmú legislatívu narúšajúcu slobodu vyznania a neurobia nijaké opatrenia, ktoré by viedli $k$ diferencovanému prístupu k vyznávačom rôznej viery, náboženstiev alebo rítov, neodporujúcich verejnému poriadku a dobrým mravom. ${ }^{40}$

Tento Wilsonov návrh však na rokovaniach o založení Spoločnosti národov neuspel. V januári a vo februári 1919 z projektu Spoločnosti národov vypadli aj menšinové klauzuly, ktoré vypracovali britský a americký právny expert Sir Cecil Hurst a David Hunter Miller. Podobne dopadol návrh lorda Roberta Cecila, ktorý si želal, aby Rada Spoločnosti národov mohla zasiahnut' proti prejavom náboženskej neznášanlivosti vlád a ich neliberálnemu postoju k iným náboženským vyznaniam..$^{41} \mathrm{~V}$ agende mierovej konferencie menšinová záležitost' ostala najmä kvôli výraznej aktivite židovských organizácií v západnej Európe a USA. ${ }^{42}$ V ich úsilí sa spájali národné sionistické ciele a reakcia na alarmujúce správy o anarchii a pogromoch, ktoré sprevádzali koniec vojny vo východnej a strednej Európe. Koncom októbra 1918 Svetová sionistická organizácia vydala Kodanský

39 SNA, OF Vavro Šrobár, šk. 4, i. č. 20, folio 97.

40 MILLER, David Hunter. The Drafting of the Covenant, 2. New York - London : G. P. Putnam's Sons 1928, s. 91.

41 Knižnica a archív Spoločnosti národov, Ženeva (SDN), S 2453, britský návrh Paktu Spoločnosti národov. 42 Bližšie FINK, Carole. Defending the Rights of Others, The Great Powers, the Jews and International Minority Protection 1878 - 1938. Cambridge : Cambridge University Press, 2004. 
manifest, v ktorom formulovala svoje ciele do štyroch základných bodov: národný štát v Palestíne, zrovnoprávnenie Židov v ostatných štátoch, národná autonómia $\mathrm{v}$ tých krajinách, kde žila židovská menšina, a zastúpenie v Spoločnosti národov. ${ }^{43}$ Bezprostredne pred mierovou konferenciou a po jej začatí sa za politickú a kultúrnu autonómiu Židov zasadzoval aj britský The Joint Foreign Committee a American Jewish Council z USA. Liberálnejšie spôsoby zabezpečenia občianskej rovnoprávnosti a náboženských slobôd pre židovských občanov mala v pláne parížska Alliance israélite universelle. Sionisti založili 25. marca 1919 Komitét židovských organizácií pri mierovej konferencii pod vedením Juliana Macka a neskôr Louisa Marshalla. Významnú úlohu v ňom zohrával aj zástupca sionistov z pol'ských zemí Nahum Sokolow. I ked’ do tohto komitétu svojich zástupcov nevyslal ani The Joint Foreign Committee ani Alliance israélite universelle, ktoré sa neusilovali o uznanie židovských národných práv a podobné snahy v Británii a Francúzsku považovali za kontraproduktívne, uzavreli s Komitétom židovských organizácií pri mierovej konferencii dohodu o lojalite a vzájomnej podpore pri presadzovaní židovských záujmov. ${ }^{44}$ Všetky zmienené organizácie pozornost' zamerali na situáciu v Rumunsku a najmä Pol'sku. Od nich vyšiel popud, aby do mierových zmlúv s novovzniknutými štátmi bola zakomponovaná medzinárodná ochrana rasových, náboženských a jazykových menšín. ${ }^{45}$ Už 20. apríla 1919 spracoval Komitét židovských organizácií pri mierovej konferencii prvý projekt ochrany národnostných menšín. Hovorilo sa $\mathrm{v}$ ňom $\mathrm{v}$ prvom rade o automatickom získaní občianstva na základe rodiska, okrem prípadov opustenia tohto územia pät' rokov pred 1. júlom 1914, alebo ak medzitým dotyčný získal iné občianstvo. Ďalej sa ochrana mala týkat’ rovnosti občianskych, náboženských, politických a národných práv a požadovalo sa zrušenie zákonov, ktoré boli s týmito ustanoveniami v rozpore. Autonómia sa mala týkat' zakladania a riadenia menšinových náboženských, dobročinných, osvetových a spoločenských organizácií, a tiež proporcionálneho zastúpenia v niektorých zastupitel'ských orgánoch. Požadovala sa garancia jazykovej rovnoprávnosti a rešpektovanie židovského posvätného dňa. Všetky tieto záruky sa mali zakotvit' v ústavách štátov a ich dodržiavanie mala sledovat' Spoločnost’ národov. Projekt tieto požiadavky zdôvodňoval tým, že vo východnej Európe vznikli štáty ako Pol'sko, Rumunsko, Československo, Juhoslávia, Grécko a d’alšie. Skoro v doslovnom znení odovzdal 10. mája 1919 zmienený komitét mierovej konferencii memorandum so svojimi oficiálnymi požiadavkami. Uviedol v ňom navyše, že „v zmysle týchto článkov židovské obyvatel'stvo [...] utvorí národnú menšinu so všetkými právami v uvedenom rozsahu. ${ }^{46}$ Memorandum Komitétu židovských organizácií pri mierovej konferencii prevzal David H. Miller a tvorilo aj podstatu menšinovej zmluvy predloženej na podpis Pol'sku.

43 SCHRAMM, Tomasz. Geneza i powstanie traktatu o ochronie mniejszości narodowych. In BLOCH, Czeslaw - ZIELIŃSKI, Zygmunt (eds.) Powrót Polski na mapę Europy. Lublin : Redakcja wydawnictw KUL, 1995, s. 299. 44 Tamže, s. 302-303.

45 FEINBERG, Nathan. La question des minorités à la Conférence de la Paix 1919-1920 et l'action juive en faveur de la protection internationale des minorités. Paris : Rousseau et Cie Editeurs, 1929.

46 SCHRAMM 1995, s. 305. 
Wilson sa k svojmu návrhu vrátil po návrate z USA, kde sa tiež oboznámil s predstavami židovských náboženských obcí o zárukách pre židovské obyvatel'stvo vo východnej Európe. Dňa 1. mája 1919 na zasadnutí Najvyššej spojeneckej rady (Rady štyroch) opätovne nastolil problematiku ochrany židovského obyvatel'stva v Pol'sku a Rumunsku. Navrhol, aby mierová zmluva s Nemeckom obsahovala články o ochrane Židov v Pol'sku a upozornil, že v tomto štáte budú žit' aj početní Nemci. Wilsonova koncepcia ochrany menšín sa opierala o rešpektovanie základných l'udských práv a slobôd; prezident USA ju sformuloval do dvoch hlavných zásad: 1. zmluvná strana sa mala zaviazat', že nezakáže a nebude zasahovat’ do slobody vyznania, náboženstva a viery, ktorá je v súlade s verejným poriadkom a morálkou, a nebude svojim občanom zasahovat' do slobody vyznania, náboženstva či viery; 2 . že všetkým rasovým a národnostným menšinám, ktoré žijú pod jej jurisdikciou, zaručí po právnej i faktickej stránke rovnaké zaobchádzanie, aké poskytuje rasovej a národnostnej väčšine svojho l'udu. ${ }^{47}$ Ďalšie materiály týkajúce sa menšinovej problematiky v nových štátoch vypracoval David Hunter Miller a sir H. Llewelyn Smith. Obidvaja boli presvedčení o tom, „že nové štáty vznikli vd'aka úsiliu a obetiam dohodových spojencov, ktorí presadili, aby novým štátom boli odstúpené územia, a preto majú právo i povinnost' vynútit' si od nich, aby z hl'adiska všeobecných záujmov zabezpečili predchádzajúce práva obyvatel'stvu, ktoré zmenilo štátnu príslušnost." ${ }^{\prime 4}$ Zároveň to malo byt' podmienkou ich uznania v nových hraniciach. V súlade s týmto stanoviskom dohodoví štátnici zriadili Komisiu pre nové štáty a menšiny, ktorá pripravovala menšinové zmluvy ako súčast’ mierových zmlúv. Stretla sa prvý raz 3. mája 1919 za predsedníctva francúzskeho diplomata Philippa Berthelota a účasti d'alších zástupcov Francúzska, Vel'kej Británie, USA, neskôr aj Talianska a Japonska. Súrna bola najmä záležitost' Československa a Pol’ska, lebo už 7. mája malo Nemecko dostat' podmienky mierovej zmluvy. Na podrobné vypracovanie klauzúl nebolo dost' času, tak sa do textu návrhu mierovej zmluvy dostal len zápis o iunctim o budúcej zmluve o menšinách, ktorá bude podpísaná zároveň s mierovou zmluvou (články 86 a 93 návrhu, neskôr Versailleskej zmluvy). ${ }^{49}$

Komisia sa spočiatku venovala len otázkam ochrany menšín v Pol'sku a Československu, ale už v prvej polovici mája svoju právomoc rozšírila aj na tie štáty, ktoré po vojne získali nové vel'ké územia, čiže na Král'ovstvo Srbov, Chorvátov a Slovincov, Rumunsko a Grécko. ${ }^{50}$ Do 16. mája pripravila návrh menšinovej zmluvy s Pol'skom, ktorý Rada štyroch analyzovala 17. mája. K už zmieneným menšinovým klauzulám pribudla ešte garancia týkajúca sa práv optantov, ktorí sa rozhodli Pol'sko opustit', aby si tam mohli ponechat' všetky nehnutel'nosti a bez poplatku vyviezt' všetok hnutel'ný majetok. Komisia pre nové štáty a menšiny a Rada štyroch sa zhodli na tom, že ochrana práv menšín, najmä židovských, sa bude týkat’ len novovzniknutých štátov a ich pripojených území. Pridali k nim

47 La documentation internationale. La paix de Versailles, 10. Paris : Editions internationales, 1932, s. 12.

48 Note by Sir Hubert Llewelyn Smith. In La documentation internationale 10, 1932, s. 15.

49 SCHRAMM 1995, s. 306.

50 MILLER, David Hunter. My diary. At the Conference of Peace. With Documents, 13. New States (Minorities). New York : [vlastným nákladom], 1925, s. 26-67. 
aj tri krajiny, ktoré vo vojne utrpeli porážku - Rakúsko, Mad’arsko a Bulharsko. Spojenci odmietli židovské požiadavky týkajúce sa kolektívnych „národných“ práv, pretože by sa tak vytvoril nebezpečný precedens aj pre vítazné vel'moci. Britský diplomat James Headlam-Morley síce navrhoval, aby sa menšiny mohli obrátit' so st’ažnost'ami na Spoločnost' národov, čím by sa zamedzilo priame zasahovanie vel'mocí do tejto záležitosti, ale zároveň zdôraznil, že systém ochrany by sa mal týkat' len nových štátov, v opačnom prípade by mohol mat' nepredvídatel'né následky vzhl'adom na francúzskych Kanad’anov, Írov, Škótov, Walesanov, Baskov a d'alšie etniká v západnom svete. ${ }^{51}$ Zástupcovia vel'mocí prijali také riešenie, že hlavné spojenecké a združené mocnosti uzavrú s vyššie uvedenými štátmi zvláštne zmluvy garantujúce menšinám základné práva. Spoločnost' národov bude mat' právo zasiahnut' v prípade ich porušenia. Návrh zmluvy o ochrane menšín dostalo Pol'sko na vyjadrenie oficiálne 22 . mája. ${ }^{52}$

Dohodová formulácia článku 93 mierovej zmluvy týkajúca sa menšinových záruk sa stretla s vel'kými výhradami najmä zo strany Pol'ska, Královstva Srbov, Chorvátov a Slovincov a Rumunska a dostala sa na program plenárneho zasadnutia mierovej konferencie 31. mája 1919. Zároveň sa tu diskutovalo o návrhu mierovej zmluvy s Rakúskom a o menšinových záväzkoch, ktoré sa mali týkat' štyroch nástupníckych krajín. Delegát Rumunského královstva Ion Bratianu vystúpil proti návrhu menšinovej zmluvy, pretože by obmedzila suverenitu jeho krajiny. Vyjadril ochotu prijat’ záväzky na ochranu menšín v rámci Spoločnosti národov, ale ostro kritizoval skutočnost', že sa mali týkat' len strednej a východnej Európy. Pol'ský delegát Ignacy Paderewski vystúpil zmierlivejšie, ale zmysel jeho vystúpenia bol rovnaký: „Pol'sko prizná všetkým rasovým, jazykovým a náboženským menšinám rovnaké práva ako svojim obyvatelom. Zaistí tým menšinám rovnaké práva, aké im priznávajú alebo v budúcnosti priznajú vel'ké mocnosti alebo západné štáty. "53 Plenárne zasadnutie 31. mája vošlo do dejín ako vzbura malých spojencov, ktorí však jednoznačne t’ahali za kratší koniec. Georges Clemenceau a Woodrow Wilson argumentovali, že dohodové a pridružené mocnosti vyhrali vojnu a sú zodpovedné za trvalý mier. Wilson jasne vyjadril, že budúci mier budú garantovat' vel'moci a „je pre nás nemožné garantovat' tie územné usporiadania, ktoré nepovažujeme za spravodlivé a nemôžeme súhlasit's ponechaním prvkov nepokoja, ktoré - ako usudzujeme - porušujú svetový mier“.54

Po uzavretí prímeria a počas prvého polroka 1919 tlač v západných krajinách neprestala prinášat' niekedy pravdivé, ale často prehnané tvrdenia nielen o krvavých incidentoch, ale aj o krutých pogromoch najmä na pomedzí východnej Haliče a Ukrajiny, kde ešte neustala občianska vojna a vojna o hranice. Túto otázku sa usiloval dat' na pravú mieru napríklad slavista Ernest Denis, expert vo francúzskom Comité d’Etudes. Spracoval materiál La question juive sur le territoire de la

51 LUNDGREN-NIELSEN, Kay. The Polish Problem at the Paris Peace Conference. Odense : University Press, 1979, s. 341-348.

52 MILLER 1925, s. 26-27.

53 SCHRAMM 1995, s. 308.

54 Tamže, s. 308. 
Pologne historique, ktorý sa našiel v materiáloch Komisie Spoločnosti národov. Bránil Poliakov pred zovšeobecňujúcimi obvineniami z antisemitizmu a poukazoval na pozitívne príklady vzájomného spolužitia, hoci neskrýval, že určité prejavy antisemitizmu boli a sú v Pol'sku prítomné. Jasne sa vyjadril proti poskytnutiu politickej autonómie Židom. Podla neho by sa tak v Pol'sku utvorila skupina, ktorá by sa dištancovala od spoločenského a štátneho života, riadila by sa len podl'a vlastného práva a rešpektovala by len vlastných predstavitel'ov. To by bolo kontraproduktívne a pravdepodobne by podl'a neho viedlo len k d'alším nepokojom a útokom na židovské obyvatel'stvo. ${ }^{55}$

Otázka, či bude menšinám priznaná právna subjektivita, patrila k základným problémom úvah o koncepcii rodiaceho sa systému aj v máji a júni 1919. Konečná odpoved' politikov, diplomatov a expertov dohodových krajín na túto požiadavku bola záporná: malo íst' o rovnoprávnost' a ochranu jednotlivca, ktorý mal mat' právo združovania a kolektívneho presadzovania vlastných potrieb.

Paderewski si vyžiadal čas na spracovanie písomnej odpovede na návrh menšinovej zmluvy.

Vo vopred pripravenom memorande, ktoré na upomínanie vel'mocí odovzdal mierovej konferencii 15. júna, zopakoval svoje ubezpečenie, že Pol’sko sa správa rovnako ku všetkým svojim občanom. Ohradil sa proti článku 93 mierovej zmluvy s Nemeckom, pretože by na jeho základe Pol'sko muselo súhlasit' so zasahovaním dohodových mocností do svojich vnútorných záležitostí. Použil pri tom historickú argumentáciu a zdôraznil, že aj delenie Pol'ska bolo dôsledkom zasahovania vel'mocí do záležitostí týkajúcich sa náboženských menšín. Protestoval v prvom rade proti sústavnej kontrole Ústavy Pol'skej republiky a jej konštitučných zákonov vel'mocami. Pol'sko sa zaväzovalo poskytnút' štátne občianstvo všetkým svojim obyvatel'om, ale uviedlo tiež, že sa nechce viazat' garantovanými menšinovými záväzkami, pretože ak minority budú cítit' vonkajšiu podporu, povzbudí to ich st'ažnosti proti Pol'sku. Väčšinové obyvatel'stvo na to bude reagovat' podráždene, čo povedie k stálemu napätiu. Namietal aj proti tomu, že vítazní spojenci nerátajú s ochranou pol’skej menšiny v Nemecku. Zvláštne židovské školstvo a privilégiá v záležitostiach osvety hodnotilo pol'ské memorandum ako nebezpečné pre jednotu štátu. ${ }^{56}$

Pol'ské argumenty prerokovala Rada štyroch 17. júna 1919 a dokonca aj David Lloyd George, ktorý ich na zasadnutí prezentoval, ich považoval za dôležité a hodné pozornosti. Došlo však len k celkom malým zmenám v pripravovanej menšinovej zmluve s Pol'skom. Napríklad jidiš mal byt' len pomocným jazykom v základných školách židovskej menšiny. Záväzky týkajúce sa nemeckej menšiny v Pol'sku sa mali vzt'ahovat' len na územie, ktoré bolo pred Vel'kou vojnou súčast’ou Nemeckej ríše. Projekt odpovede na Paderewského memorandum opät' vypracovala Komisia pre nové štáty a menšiny. Po jeho prerokovaní v Rade štyroch

55 Tamže, s. 301-302, 323.

56 MILLER 1925, text pol'ského memoranda s. 170-179. 
23. júna došlo aj na odpoved', ktorú dostal Paderewski o deň neskôr. Podpísal ju Georges Clemenceau ako predseda mierovej konferencie, išlo však o odpoved' Najvyššej rady konferencie na základe konsenzu expertov a štátnikov vít’azných mocností, najmä Francúzska, USA a Vel'kej Británie. Odpoved' Pol'sku z 24. júna 1919 sa odvolala na medzinárodnoprávnu prax 19. storočia, najmä na ustanovenia Berlínskeho kongresu: podl’a nich sa zaužívalo, že štát, ktorý získava medzinárodné uznanie, je povinný rešpektovat' niektoré zásady vládnutia a záväzky formou medzinárodných dohôd. Odpoved' sa neobmedzovala na ochranu náboženských menšín, ale upozorňovala aj na celkom novú situáciu, ktorá si vyžadovala nové opatrenia: „Územia, prechádzajúce k Pol’sku alebo k iným štátom, nevyhnutne zahrnujú početné obyvatel'stvo, ktoré rozpráva jazykom inej rasy a nie tej, ku ktorej bude pripojené. Dlhé roky nepriatel'stva tieto rasy výrazne rozdelili. Dúfame, že sa l'ahšie zmieria so svojou novou situáciou, ak budú od začiatku vediet', že dostanú potrebné záruky ochrany proti nespravodlivosti alebo útlaku. Môžeme dokonca dúfat', že samotná existencia týchto záruk konkrétne napomôže vytúžené zmierenie a nebude potrebné tieto záväzky d'alej posilňovat". ${ }^{\prime \prime}$

Odpoved' trvala na tom, aby Pol'sko poskytlo svojim židovským občanom zvláštne záruky. Zároveň Clemenceau výslovne uviedol, že tieto klauzuly dohodovej zmluvy s Pol'skom neznamenajú uznanie Židov ako autonómneho alebo zvláštneho politického spoločenstva vnútri pol'ského štátu. Vyučovanie iného ako pol'ského jazyka nesmelo napomáhat' rozvíjat' separatizmus menšín a pol'ský štát mal dostat' právo zaviest' povinné vyučovanie pol'štiny do všetkých škôl na vlastnom území. Novým prvkom pri ochrane menšín bolo ich garantovanie Spoločnostou národov.

Paderewski sa 26. júna 1919 opät' dožadoval reciprocity pri ochrane nemeckých menšín v Pol'sku a pol'ských v Nemecku. Prioritou však bolo, aby Nemecko vôbec podpísalo mierovú zmluvu. Nemecká delegácia sa vo svojej odpovedi z 29. mája 1919 postavila proti pol'skému koridoru, spochybnila pripojenie Horného Sliezska k Pol'sku a zároveň sa vyjadrila aj k menšinovej problematike. Požadovala medzinárodnú ochranu „národných“ menšín v rámci Spoločnosti národov. Žiadala, aby mierová zmluva obsahovala určité záruky pre nemecké menšiny, ktoré sa v dôsledku územných zmien ocitnú v inom štáte (najmä v Pol'sku). Vyslovila želanie, aby sa utvorila kultúrna autonómia na územiach obývaných menšinou a vyslovila ochotu zachovávat' rovnaké zásady voči cudzím menšinám na svojom území. Návrh mierovej zmluvy bol výsledkom t’ažko hladanej zhody medzi americkými, britskými a francúzskymi predstavami, preto ho vel’moci 16. júna 1919 vrátili Nemecku bez zmien a s ultimatívnou žiadostou o podpis. Rozhodli však, že v Hornom Sliezsku sa bude konat' plebiscit a ubezpečili Nemecko, že sú „pripravené poskytnút’ nemeckým menšinám záruky týkajúce sa vzdelávania, náboženstva a kultúry na tých územiach, ktoré budú oddelené od Nemecka a prejdú pod právomoc štátov vytvorených (mierovými) zmluvami. Tieto záruky

57 Tamže, s. 215-222, list Clemenceaua Paderewskému 24. 6. 1919. Príloha C k 21. schôdzi Komisie pre nové štáty. 
budú pod ochranou Spoločnosti národov. “58 To vysvetl'uje prijaté riešenie, podla ktorého menšinová zmluva s Pol'skom zaväzovala tento štát rešpektovat' práva nemeckej menšiny len na území, ktoré predtým patrilo Nemecku. Záruky sa netýkali napríklad nemecky hovoriacich občanov na území bývalej Kongresovky. V snahe získat' nemecký podpis na mierovej zmluve mocnosti nepožadovali, aby sa Nemecko zaviazalo rešpektovat' práva svojich pol'sky hovoriacich občanov. Zároveň upokojovali Paderewského tým, že podobné záruky budú od Nemecka žiadat' pri jeho vstupe do Spoločnosti národov. V roku 1926, ked' sa rokovalo o vstupe Nemecka do Spoločnosti národov, vel'moci sl'ub daný Pol'sku nesplnili. Pozícia Nemecka vo svete bola už natol'ko silná, že si vtedy úspešne nárokovalo stále miesto v Rade Spoločnosti národov a blokovalo rovnakú žiadost' Pol'ska. O ochrane pol'sky hovoriacich nemeckých občanov sa už nehovorilo. V júni 1919 situácia Pol'ska, ktoré ešte nemalo stanovené všetky hranice, mu nedovol'ovala, aby sa d'alej vzpieralo, preto menšinovú zmluvu zároveň s Versailleskou zmluvou s Nemeckom 28. júna 1919 podpísalo. Získalo tak medzinárodnoprávne uznanie piatich vel'mocí a na oplátku sa zaviazalo, že bude prijímat' len také zákony, ktoré nebudú $v$ rozpore $s$ jeho menšinovými záväzkami ${ }^{59} \mathrm{Na}$ celom území Polska platili klauzuly týkajúce sa židovského školstva, kultúry a charitatívnych spolkov. Jeden špeciálny článok zaručoval občanom židovského vyznania právo na rešpektovanie ich sviatočného dňa aj zo strany súdnej moci a štátnej správy. Pol'sko sa okrem iného zaviazalo, že v sobotu nebude organizovat' ani parlamentné vol'by, ani vol'by do miestnej samosprávy.

Československá problematika sa v komisii dostala na program až po odsúhlasení pol'ského „vzoru“ zmluvy medzi spojencami a novým štátom. Ale už predtým sa o riešení problematiky menšín diskutovalo na pôde Komisie pre česko-slovenské záležitosti. Na rozdiel od Pol'ska v nej židovská problematika nezohrávala nijakú úlohu. „Rabovačky“ boli záležitost'ou týkajúcou sa konca októbra a začiatku novembra 1918; v prvej polovici roka 1919 západná tlač neobviňovala Československo z antisemitizmu. Z hladiska bezpečnosti Československa znepokojoval najmä vysoký počet etnických Nemcov v Českých krajinách. Pôvodne sa rátalo s tým, že ich počet sa zníži tým, že využijú možnost' opcie pre Rakúsko alebo Nemecko. ${ }^{60}$ Československo bolo v chúlostivej situácii najmä kvôli konfliktu s Mad’arskou republikou rád, ktorý vypukol v súvislosti s vojenským obsadzovaním „územia Rusínov na juh od Karpát“ (oficiálny termín, ktorý mierová konferencia v Paríži používala pre neskoršie ustálený názov Podkarpatská Rus) v rámci hraníc, o ktorých už dlhšie rokovala teritoriálna Komisia pre česko-slovenské záležitosti na mierovej konferencii. Územie obsadili rumunské a československé vojská pod velením dohodových, najmä francúzskych generá-

58 SDN, R 1613, 41/116/116.

59 Obsah polskej menšinovej zmluvy bližšie FERENČUHOVÁ, Bohumila. Ochrana národnostných menšín v Spoločnosti národov a československá politika. In BENEŠ, Zdeněk - KOVÁĆ, Dušan - LEMBERG, Hans (ed.) Hledání jistoty v bouřlivých časech. Pro Česko-německou a Slovensko-německou komisi historiků vydává nakladatelství Albis international, 2006, s. 115-116.

60 Pozri FERENČUHOVÁ, Bohumila. Vel'mocenský diktát alebo vedecký problém? Rokovanie o hraniciach Československa v prvej fáze mierovej konferencie v Paríži roku 1919. In ŠVORC, Peter -HARBUL'OVÁ, Lubica (ed.) Stredoeurópske národy na križovatkách novodobých dejín 1848 - 1918. Prešov : Universum, 1999, s. 246. 
lov. Bolo to pred podpísaním mierovej zmluvy s Rakúskom a Mad’arskom a definitívnym určením československo-mad’arskej hranice. Kým vojenské velenie Dohody bolo nútené rokovat’ o demarkačnej čiare medzi rumunskými a československými ozbrojenými silami, Rada ministrov zahraničných vecí Dohody požiadala 5. mája Komisiu pre česko-slovenské záležitosti, aby jej oznámila, akú podobu by mala mat' podla predbežných mierových podmienok rusínska autonómia. Komisia sa zišla 15. mája 1919 a na rokovanie zavolala aj Edvarda Beneša. Ten zasadil problém do všeobecného menšinového kontextu. Vysvetlil, že československá vláda mieni podporovat’ všetky trendy vývoja k federálnej organizácii celého štátu, ale zatial' by bolo podla neho predčasné prijat' konkrétny decentralizačný plán. Bol ochotný rokovat' o zvláštnom štatúte s Rusínmi, nie však s inými menšinami. ${ }^{61}$ Francúzsky zástupca Jules Laroche podobné riešenie považoval za precedens neželanej žiadosti Rakúska, aby pripravovaná Saint-germainská zmluva zabezpečila zvláštny štatút aj pre českých Nemcov. Britský zástupca navrhol, aby autonómia Rusínov tvorila súčast' zvláštnej zmluvy medzi spojencami a Československom, s čím Beneš súhlasil. Komisia pre česko-slovenské záležitosti ho požiadala, aby predložil písomné memorandum o tom, akú podobu zvláštneho štatútu je československá vláda ochotná poskytnút' rusínskemu obyvatel'stvu. Požadovaný návrh dostala o dva dni neskôr. Československý návrh zo 17. mája zdôraznil skutočne výnimočné postavenie, ktorého sa malo územiu Rusínov dostat'. Kontrastoval s ním plán na centralizáciu jadra republiky, ktorá sa mala delit’ na kraje riadené krajským náčelníkom, pričom krajské rady, ktoré mu mali pomáhat', mali mat' len administratívnu a kontrolnú funkciu ${ }^{62}$ Dňa 20. mája Komisia pre česko-slovenské záležitosti odporúčala Rade ministrov zahraničných vecí, aby sa memorandum o právnom postavení Rusínov na juh od Karpát, ktoré predložil čs. minister zahraničných vecí, stalo základom vzt’ahov medzi Československou republikou a Rusínmi. V tom istom čase Beneš odovzdal mierovej konferencii aj nótu s československým programom riešenia národnostnej otázky. ${ }^{63}$

Československo sa ukázalo voči požiadavkám vel'mocí týkajúcich sa menšín ústretovejšie ako Pol'sko a Rumunsko. Na 10. schôdzi Komisie pre nové štáty a menšiny, ktorá sa konala 20. mája 1919 na Quai d'Orsay, Philippe Berthelot prečítal Benešovu nótu o národnostnom usporiadaní Československej republiky. Hned' v prvom článku sa uvádzalo, že čs. vláda hodlá usporiadat' štát na základe národných práv a švajčiarskych konštitučných zásad, rešpektujúc zároveň špecifické české podmienky. V d’alších sa slubovalo zavedenie všeobecného volebného práva, pomerné zastúpenie národností v parlamente a slobodné používanie iných jazykov v školstve, administratíve aj na súdoch. V ôsmom článku stálo, že oficiálnym jazykom bude čeština, v zahraničí bude štát známy ako česko-

61 KOLÁŘ, František. Podkarpatská Rus na Pař́žské mírové konferenci. In Československá historická ročenka 1997, s. 66; Archives du Ministère des Affaires étrangères, Paris (AMAE), Commisssion des affaires tchéco-slovaques, Procès verbal No 12, Séance du 15 mai 1919, s. 104-107.

62 La Paix de Versailles 10 1932, s. 71-73.

63 DEJMEK, Jindřich - KOLÁŘ, František (ed.) Dokumenty československé zahraniční politiky. A/2/1. Československo na pař́ž́ské mírové konferenci 1918 - 1920. Praha : Ústav mezinárodních vztahů, Univerzita Karlova v Praze - nakladatelství Karolinum, Historický ústav AV ČR, 2001, s. 324, dokument 204. 
-slovenský, v praxi však nemčina bude druhým rovnoprávnym jazykom krajiny. Čs. vláda totiž chce v každodennom živote vyhoviet' svojmu obyvatel'stvu, a preto zavedie podobný liberálny režim ako Švajčiarsko. ${ }^{64}$

Členovia komisie konštatovali, že prísl’uby idú d’alej, ako vôbec môžu od Československa žiadat'. ${ }^{65} \mathrm{~V}$ stanovisku Komisie pre nové štáty a menšiny sa uvádzalo, že najzávažnejším problémom pre Československo bude približne trojmiliónová nemecká menšina. Nemci v Čechách mali do roku 1918 privilegované postavenie a dominantný vplyv v štáte, bolo to vysoko rozvinuté a schopné obyvatel'stvo, nie bez agresívnych prejavov. „Je jasné, konštatovala správa komisie, že „prosperita a možno aj existencia nového štátu bude závisiet’ od toho, či sa mu podarí integrovat’ Nemcov ako ochotných občanov." Písalo sa v nej aj to, že riešenie tejto obrovskej úlohy má dosah na konštitučný charakter štátu a množstvo jeho inštitúcií, a bolo preto lepšie „ponechat' ho na samotných Čechov“. So zretel'om na Benešove sl'uby o liberálnom prístupe k menšinám a nemeckej menšine zvlášt' sa komisia rozhodla nevenovat' zvláštnu pozornost' tejto najvplyvnejšej a najorganizovanejšej československej menšine, ale uspokojit' sa len s najvšeobecnejšími zásadami, ktoré Československo bezpochyby prijme bez akýchkol'vek výhrad. ${ }^{66}$ Pokial' išlo o autonómiu Rusínov, „Komisia sa vo svojom návrhu klauzúl úzko pridržiavala návrhov a do značnej miery aj aktuálnych slov pána Beneša; v niektorých prípadoch sú však až privel'mi detailné a komisia myslí, že nie je potrebné ani želatel'né zmluvne zaväzovat'Česko-Slovenský štát až do presných detailov." ${ }^{\text {"67 }}$

Výsledkom práce komisie, ktorá zasadala do septembra 1919, boli jednak návrhy na články o ochrane menšín v mierovej zmluve s Nemeckom, Rakúskom a Bulharskom, jednak príprava tzv. minoritných zmlúv s Polskom (podpísaná 28. júna 1919 vo Versailles), s Československom (podpísaná v Saint-Germain-en-Laye 10. septembra 1919), s Královstvom SHS (akceptovalo ju deklaráciou 5. decembra 1919), s Rumunskom (podpísaná v Paríži 9. decembra 1919) a s Gréckom (podpísaná v Sèvres 10. augusta 1920), ktoré tvorili základ medzinárodnej ochrany menšín po prvej svetovej vojne. Materiály 64 zasadnutí komisie boli publikované. ${ }^{68}$

V mierovej zmluve medzi spojeneckými a združenými mocnost’ami a Rakúskom podpísanej 10. septembra 1919 v Saint-Germain-en-Laye sa Československo v článku 57 zaviazalo, že prijme vo zvláštnej zmluve ustanovenia o ochrane záujmov tých obyvatelov krajiny, ktorí sa od ostatných líšia rasou, jazykom a vyznaním. Na základe tohto záväzku bola vypracovaná zvláštna zmluva medzi hlavnými spojeneckými a združenými mocnostami a Československom podpísaná zároveň so Saint-germainskou mierovou zmluvou, ktorá podrobnejšie rozvádzala

64 MILLER 1925, s. 6-70; Pozri tiež KUBU, Eduard. Cíle a handicapy politiky Edvarda Beneše ve Společnosti národů. In BENEŠ - KOVÁČ - LEMBERG 2006, s. 58-62.

65 FERENČUHOVÁ 2006, s. 90-91.

66 Annex (B) to eleventh meeting Report No.3, Czecho-Slovakia, In La Paix de Versailles 10, 1932, s. 123.

67 Tamže, s. 123.

68 Tamže. 
všeobecné ustanovenia mierovej zmluvy s Rakúskom týkajúce sa ČSR, jej povinností ako nástupníckeho štátu vrátane záväzkov voči vlastnému menšinovému obyvatel'stvu. Obidve zmluvy v plnom rozsahu prevzal československý právny poriadok zákonmi 507 a 508 Zb. z. a n. z 31. decembra $1921 .{ }^{69}$

$\mathrm{V}$ jej preambule sa konštatovalo, že „spojenie, ktoré bolo predtým medzi starým král'ovstvom českým, markrabstvom moravským a vojvodstvom sliezskym na jednej a d’alšími územiami bývalého mocnárstva rakúsko-uhorského na druhej strane navždy úplne prestalo [...], že národy Čiech, Moravy a časti Sliezska, ako aj národy Slovenska sa z vlastnej vôle rozhodli spojit' a aj sa spojili trvalým spôsobom za tým účelom, aby utvorili jednotný, zvrchovaný a samostatný štát zvaný Československá republika, ku ktorým sa pripojili aj národy Rusi [vo francúzskom origináli „Ruthénie"] na juh od Karpát $t^{\text {"70 }}$

V zmluve bol uplatnený historický princíp, vôla národov - čiže sebaurčovacie právo, a tiež potvrdenie uznania republiky ako už existujúceho suverénneho štátu zo strany vít’azných vel'mocí. Ďalšie články tejto zmluvy obsahovali záruky rovnakého zaobchádzania so všetkými občanmi štátu bez rozdielu rasy (národnosti), náboženstva a jazyka. Československo sa zaviazalo v prvom článku, že „ustanovenia obsiahnuté v článku 2 až 8 tejto hlavy budú uznané za základné zákony, že žiadny zákon, žiadne nariadenie, ani žiadny úkon úradný proti nim nebude mat' moc ". ${ }^{71}$ Zaručilo právo na život, na osobnú slobodu a tiež slobodu vyznania pre všetkých svojich občanov bez rozdielu pôvodu, národnosti, jazyka, rasy alebo náboženstva. Ďalšie záväzky sa týkali štátneho občianstva: občanmi ČSR sa mali stat' bez akýchkol'vek formalít všetci nemeckí, rakúski a uhorskí štátni príslušníci žijúci v čase uvedenia zmluvy do platnosti na územiach, ktoré pripadli Československu. Títo však mali dostat' právo opcie, ktoré mohli využit' do dvoch rokov od uvedenia zmluvy do platnosti; v takom prípade sa mali prest'ahovat' do 12 mesiacov do krajiny, ktorú si zvolili, pričom si mohli v pôvodnej krajine ponechat' nehnutel'ný majetok a vziat' so sebou všetky hnutel'nosti. Československý návrh, aby sa v zmluve výslovne uviedlo, že s majetkom budú môct' nakladat' „za rovnakých podmienok ako československí štátni príslušníci“, Komisia pre nové štáty a menšiny odmietla ako nepotrebný. Článok štyri stanovil, že ak sa niekto narodil na československom území, stačilo to na získanie štátneho občianstva v tom prípade, ak dotyčný nemal občianstvo inej krajiny. Československo malo pripomienky aj k týmto zásadám a dosiahlo niektoré upresnenia a obmedzenia záväzkov týkajúcich sa štátneho občianstva, ich väzbu na bydlisko či domovské právo. ${ }^{72}$ Bez výhrad sa zaviazalo rešpektovat' v teórii i v praxi rovnost' každého občana pred zákonom, rovnaké poskytovanie občianskych aj politických práv a rovnakú šancu na uplatnenie bez zretela na pôvod (rasu,

69 MOSNÝ, Peter. Podkarpatská Rus. Nerealizovaná autonómia. Bratislava : Slovak Academic Press, 2001, s. 17-18.

70 Sbírka zákonů a nařízení státu československého, částka 134, vydáno 31. prosince 1921, s. 2301. V českom úradnom preklade uverejnenom až po prijatí Ústavy ČSR sa na rozdiel od originálneho textu uvádza názov republiky jedným slovom, bez spojovníka.

71 Článok 1 zákona č. 508/1921 Zbierky zákonov a nariadení.

72 Podrobná právna analýza por. MOSNÝ 2001, s. 19-20. 
národnost'), náboženstvo či jazyk. Československým občanom, ktorí patrili k rasovým, náboženským alebo jazykovým menšinám, sa zaručovalo rovnaké právo ako iným československým občanom zakladat', riadit' a kontrolovat' na vlastné náklady charitatívne, náboženské a sociálne inštitúcie a školy a slobodne v nich používat' vlastný jazyk a praktizovat’ svoje náboženstvo. Zvláštne články zmluvy sa týkali menšinových jazykov a zakazovali obmedzovat' ich používanie v osobnom živote a v obchode, pri náboženských úkonoch, v tlači, publikáciách a na verejných zhromaždeniach. Pred súdom sa príslušníkom menšín zaručovalo právo používat' svoj jazyk v písomnom aj ústnom prejave. Článok devät’ sa vztahahoval na mestá a okresy, kde žili početní občania, hovoriaci iným jazykom ako česko-slovenským. $V$ tom prípade im zmluva zaručovala školy s vlastným vyučovacím jazykom, vláda však mala právo nariadit' v nich povinné vyučovanie češtiny. Menšiny mali právo využívat' v proporčnej miere verejné (štátne či lokálne) fondy vo svoj prospech na vzdelávanie, cirkevné účely alebo dobročinnost'. Druhá kapitola začínala článkami 10 - 13, venovaným autonómnemu štatútu Podkarpatskej Rusi, a posledný 14. článok zmluvy stanovil, že záruky, týkajúce sa osôb patriacich $\mathrm{k}$ rasovým, náboženským a jazykovým menšinám, predstavujú záväzky medzinárodného záujmu, ktoré bude garantovat' Spoločnost' národov. Nebudú sa môct' menit’ bez súhlasu väčšiny Rady Spoločnosti národov. Československo v ňom vyjadrilo súhlas s tým, že každý člen Rady bude mat' právo oznámit' Spoločnosti národov porušenie (infraction) alebo nebezpečenstvo porušenia prijatých záväzkov, a s tým, že Rada bude d'alej postupovat' podla vlastného uváženia a podla okolností vyberie vhodné a efektívne prostriedky d’alšieho postupu. Prípadný spor bol považovaný za spor medzinárodného charakteru a mohol byt' predložený na posúdenie Stáleho súdu medzinárodného práva podla článku 14 Paktu Spoločnosti národov.

Československo bez väčších námietok začlenilo svoje záväzky do ústavy. Na rozdiel od terminológie Spoločnosti národov šiesta hlava ústavy uzákonila ochranu „národných", náboženských a rasových menšín a navyše podla článku 134 „akýkol'vek spôsob násilného odnárodňovania je nedovolený", pričom nezachovávanie tejto zásady môže zákon prehlásit’ za konanie trestné. ${ }^{73}$ Československá ústava $v$ súlade $s$ tradičným stredoeurópskym chápaním stotožnila národnost' s jazykom, nemenovala výslovne jazykové menšiny, ale zahrnula ich do pojmu „národných menšín“.

Systém ochrany národnostných menšín prešiel po podpísaní mierových zmlúv d’alším vývojom v každodennej praxi na pôde Spoločnosti národov. Táto sa podujala garantovat' $\mathrm{v}$ prvom rade ochranu osôb patriacich $\mathrm{k}$ „rasovým, náboženským a jazykovým menšinám"v nových alebo podstatne zväčšených štátoch stredno-východnej Európy. V oficiálnych dokumentoch Spoločnosti národov sa nepoužíval dnes zaužívaný anglický termín „national minority“ či francúzsky „minorité nationale“.

73 Dokumenty slovenskej národnej identity a štátnosti, 2, Bratislava : Národné literárne centrum, 1998, s. 116, dokument 194. 
Ešte pred ratifikáciou zmlúv s menšinovými záväzkami a uplatnením ich garantovania zo strany Spoločnosti národov začali prichádzat’ do Ženevy telegramy, listy aj objemné publikácie so st’ažnostłami na postavenie menšín v nových štátoch. Početné dokumenty, ktoré prichádzali do menšinovej sekcie sekretariátu Spoločnosti národov jasne ilustrovali závažnost' zmien, ktoré sa obyvatel'stva silno a osobne dotýkali. Najzávažnejšie boli sociálne problémy späté so stratou existenčných istôt určitých skupín obyvatel'stva. V Československu súviseli najmä s rozsiahlou agrárnou reformou. Množstvo l’udí aj z Československa sa Spoločnosti národov st'ažovalo, že po rozpade habsburskej monarchie im ani jeden z nástupníckych štátov nechcel z rôznych administratívnych dôvodov priznat' štátne občianstvo. Pridávali sa k tomu existenčné problémy súvisiace s neplatením starobných a invalidných dôchodkov. Ani jedna z petícií, ktoré na tieto okolnosti upozorňovali, nebola na sekretariáte Spoločnosti národov odložená bez zodpovedajúcej právnej analýzy či postup vlády nebol v rozpore s menšinovými záväzkami. Pritom účelom nebol postih, ale hl'adanie riešení s tým ciel’om, aby sa situácia nových štátov v súvislosti s existenciou menšín nevyostrila. Od jesene 1920 sa stažnosti v súlade s uznesením Rady Spoločnosti národov považovali za petíciu s informačnou hodnotou, čiže nie za súdnu „žalobu“, čo často nechápali právnici vlád so záväzkami, ale ani tí, na ktorých sa obracali menšinoví petenti. Rozhodnutie o d'alšom postupe zostávalo v kompetencii členov Rady, menšinová sekcia sekretariátu však zohrávala dôležitú úlohu pri zhromažd’ovaní, analýze a vyhodnocovaní materiálov a tiež v styku s vládami štátov s menšinovými záväzkami. Vykonávala akúsi poradenskú službu už na začiatku legislatívneho procesu v nástupníckych štátoch, pri príprave zákonov týkajúcich sa štátneho občianstva, školstva, používania jazykov, agrárnej reformy a podobne. Skúmala nielen na základe menšinových petícií, ale aj novinových správ a informácií, ktoré si vyžiadala od vlád, či pripravované zákony nie sú v rozpore s ich menšinovými záväzkami. Aj prácu právnych expertov v menšinovej sekcii (Erik Colban, Pablo de Azcárate a iní) môžeme priradit’ k humanitárnemu a transnárodnému obratu - precitnutiu - počas vystupovania z prvej svetovej vojny. 0 iných písali napríklad Dzovinar Kévonian či Jean-Michel Guieu, alebo Bruno Cabanès. ${ }^{74}$

Problematické zostáva uplatňovanie ochrany menšín v 30. rokoch 20. storočia, ked' sa Spoločnost' národov nedokázala rozhodne postavit' proti tým štátom, ktoré už od roku 1933 diskriminovali židovskú menšinu, najmä po prevzatí politickej moci v Nemecku nacistami. Franz Bernheim, ktorý našiel útočisko pred prenasledovaním v Prahe, podal 12. mája 1933 v Spoločnosti národov petíciu, ktorá obsahovala závažné fakty o porušovaní občianskych práv, diskriminácii a ohrození rasovej menšiny v Nemecku. Československo a Pol'sko sa vtedy spoločne pokúsili uplatnit' na pôde Spoločnosti národov štvrtú rezolúciu Rady Spoločnosti národov z roku 1922, podla ktorej mali všetky štáty rešpektovat’ práva

74 CABANES, Bruno. The Great War and the Origins of Humanitarianism. Cambridge : Cambridge University Press, 2014; KEVONIAN, Dzovinar. Les juristes, la protection des minorités et l'internalisation des droits de l'homme. In Relations internationales, 149, 1, 2012, s. 57-22; GUIEU, Jean-Michel. Les juristes français, la Société des Nations et l'Europe. In BARIÉTY, Jacques (ed.) Aristide Briand, la Société des Nations et l'Europe, 1919 - 1932. Strasbourg : Presses universitaires, 2007, s. 185-199. 
príslušníkov menšín aspoň na úrovni všeobecných zásad rovnakého zaobchádzania a nediskriminácie. Prijatie rezolúcie valného zhromaždenia zablokovalo Nemecko aj Taliansko, ktoré čoskoro Spoločnost' národov opustili. ${ }^{75}$

Prežívanie posledných dní po prvej svetovej vojne na Slovensku, v Českých krajinách či vo Francúzsku bolo odlišné. Na Slovensku neistota pretrvávala dlho, nenájdeme tu jednoznačných vítazov a porazených, vinníkov a nevinných. Z národného hladiska môžeme chápat' vznik Československej republiky ako oslobodenie a cestu $\mathrm{k}$ demokracii pre všetkých, aj pre príslušníkov menšín. Zo sociálneho hl'adiska život ostal t’ažký. Generácia tých, čo sa narodili niekol'ko rokov po ukončení druhej svetovej vojny, vníma posledných sto rokov ako súčasnost' aj preto, že posledné dni prvej i druhej vojny im sprostredkovali priamo rodičia a starí rodičia, bolo by ich teda treba skúmat' v rovine pamäti a zabúdania, pripomínania či zakrývania niektorých stránok histórie. V dedinských kronikách a rodinných spomienkach zalovili niektorí autori beletrie až po dlhých rokoch. Rôzne postavy románu Alfonza Bednára Hromový zub si nevdojak pripomínajú „rabovačky“ a bezprostredné odvety za ne. „Ponáhl'ala sa, myslela na hrubý orechový konár. (Dubovania ešte spomínajú, ako sa bála toho orecha. Od rabovačiek ju desil najmä spodný hrubý konár, plúca a srdce jej zasekoval strachom)". [...] „Karácsonyi pomaly zašiel za Hasalov orech, zastal, sedel v aute a díval sa na spodný, najhrubší konár. Tu vraj viseli ôsmi, pomyslel si. Šiesti len tak naslepo, dvaja naostro - koho sa opýtat', kto? Vojna má vel'mo hrubý, vel'mo dlhý chvost".76 Tiene dvoch obesených bez súdu nezmiznú z pamäti dediny ani potom, ked' sa jej obyvatelia rozhodnú tristoročný orech, na ktorom sa tak stalo, zot'at' a vyklčovat' aj s koreňmi.

75 FERENČUHOVÁ, Bohumila. Silné a slabé stránky medzinárodnej ochrany menšín: od Spoločnosti národov k Európskej únii. In ŠRAJEROVÁ, Olga (ed.) Otázky národní identity - determinanty a subjektivní vnímání v podmínkách současné multietnické společnosti. Opava : Slezský ústav Slezského zemského muzea v Opavě, Dokumentační a informační středisko Rady Evropy při Evropském informačním středisku UK v Praze, 2001, s. 47-63.

76 BEDNÁR, Alfonz. Hromový zub. Bratislava : Slovenský spisovatel', 1964.

Cituj:

FERENČUHOVÁ, Bohumila. Vystúpenie z Vel'kej vojny prostredníctvom práva. Československo, jeho menšiny a ich ochrana v Spoločnosti národov. In Forum Historiae, 2018, roč. 12, č. 2, s. 50-73. ISSN 1337 6861.

PhDr. Bohumila Ferenčuhová, DrSc.

Oddelenie novších dejín

Historický ústav SAV,

P. 0. Box 198,

Klemensova 19,

81499 Bratislava

histfere@savba.sk 